\title{
Response of Wheat Productivity to Different Rates of Compost and Ni- trogen Fertilizer Under New Valley Conditions
}

Mosslem, S.H.A. ${ }^{2}$; F.M.F. Abdel-Motagally ${ }^{1}$; G.R. El-Nagar ${ }^{1}$ and R.A. Dawood ${ }^{1}$

${ }^{1}$ Agronomy Department, Faculty of Agriculture, Assiut University, Egypt.

${ }^{2}$ Graduate Student, Agron. Dept., Agriculture, Assiut University, Egypt.

\section{Abstract:}

Two field experiments were conducted at El-Dakhla Oasis, New Valley Governorate, Egypt, during the two winter growing seasons of 2011/2012 and $2012 / 2013$ to investigate the effect of three date palm compost rates $(0,5$ and 10 $\mathrm{m}^{3}$ fed. $\left.^{-1}\right)$ and three nitrogen fertilizer rates $\left(50,70\right.$ and $\left.90 \mathrm{~kg} \mathrm{~N} \mathrm{fed.}{ }^{-1}\right)$ on the yield and yield components of bread wheat in the New Valley. The most important findings could be summarized as follow:

- Generally, yield and its attributes of wheat increased by adding compost. Application of $5 \mathrm{~m}^{3}$ fed. $^{-1}$ compost treatment gave the tallest plants and the maximum straw and grain yields fed. ${ }^{-1}$, while application of $10 \mathrm{~m}^{3} \mathrm{fed}^{-1}$ compost treatment gave the highest values of spike length, spikelets number spike ${ }^{-1}$ and 1000 -grains weight in both seasons, as well as application $10 \mathrm{~m}^{3} \mathrm{fed}^{-1}$ and $5 \mathrm{~m}^{3}$ fed. ${ }^{-1}$ compost treatments gave the maximum spikes number $/ \mathrm{m}^{2}$ in the $1^{\text {st }}$ and the $2^{\text {nd }}$ seasons, respectively.

- Increasing nitrogen fertilizer rate up to $70 \mathrm{~kg}$ fed. ${ }^{-1}$ increased yield and its components of wheat in both growing seasons. The maximum values of plant height, spikes number $/ \mathrm{m}^{2}$ and straw and grain yields fed. ${ }^{-1}$ were obtained by using $70 \mathrm{~kg} \mathrm{~N}$ fed..$^{-1}$, while the tallest spike and the heaviest 1000-grains were obtained by using $90 \mathrm{~kg} \mathrm{~N}$ fed. ${ }^{-1}$ in both seasons.

- The tallest plants and the maximum values of spikes number $\mathrm{m}^{-2}$ and straw yield fed. ${ }^{-1}$ were recorded by applying $5 \mathrm{~m}^{3}$ fed. $^{-1}$ compost with $70 \mathrm{~kg} \mathrm{~N}$ fed. ${ }^{-1}$ rate interaction treatment, while the maximum grain yield was recorded by applying $10 \mathrm{~m}^{3}$ fed. $^{-1}$ compost with $70 \mathrm{~kg} \mathrm{~N}$ fed. ${ }^{-1}$ rate interaction treatment in both seasons. On the other hand, the highest values of spike length and spikelets number spike ${ }^{-1}$ were recorded by applying $10 \mathrm{~m}^{3}$ fed. $^{-1}$ compost with $90 \mathrm{~kg} \mathrm{~N}$ fed. ${ }^{-1}$ rate in both seasons, while the heaviest 1000-grains weight were recorded by applying $10 \mathrm{~m}^{3}$ fed. $^{-1}$ or $5 \mathrm{~m}^{2}$ fed. $^{-1}$ compost with $90 \mathrm{~kg} \mathrm{~N}$ fed. ${ }^{-1}$ rate interaction treatments in both seasons.

Keywords: Date palm compost, grain yield, nitrogen fertilizer and wheat.

Received on: 8/4/2014

Accepted for publication on: 28/4/2014

Referees: Prof. Inaam H. G. Mohamed Prof. Eman M. Taha 


\section{Introduction:}

Wheat is the dominant grain crop of the world commerce. It is occupying an important part of the daily diet of millions of people. In Egypt, increasing productivity of wheat becomes a most to overcome unusual increase in population. Using compost considered one of many ways to reduce the applied quantities of mineral nitrogen fertilizer. The organic matter is used to improve soil health as well as supplying plant nutrients. Various types and sources of organic wastes are utilized in agricultural but most of these materials remain unutilized, especially in resource poor countries. Composting provides an effective and environment friendly procedure of organic waste disposal (Millner et al., 1998). Compost application improved all the growth parameters (Bajpai et al., 2002). Additions of $50 \mathrm{~m}^{3}$ farmyard manure ha ${ }^{-1}$ significantly increased plant height, number of panicles $\mathrm{m}^{-2}$, panicle length, 1000-grain weight and grain and straw yields (Bassal and Zahran, 2002). The organic manure and compost are important in sustaining farming by providing plant N-supply (Korsaeth et al., 2002). The organic matter in various forms and at various stages of decomposition has been used in soil in tons $\mathrm{ha}^{-1}$ for improvement and crop productivity (Terrance et al., 2004). The organic manures and date palm compost significantly increased the plant height, number of spikes $\mathrm{m}^{2}$, spike length, grain yield, straw yield, biological yield and 1000-grain weight over untreated control (Ibrahim et al., 2008; ElGhamry et al., 2009 and Mohammed, 2009). Long-term additions of organic manure have the most beneficial effects on grain yield of wheat and maize (Liu et al., 2010). The application of bio and/or farmyard manure in combination with NPK significantly increased plant height, number of spikelets spike ${ }^{-1}$, spike length, 1000-grain weight and grain yield fed. ${ }^{-1}$ (Agamy et al., 2012).

Egyptian soil are known to be poor in available nitrogen due to their low content of organic matter and the small amounts of organic manures added to them annual. Therefore, nitrogen application is considered one of the key factors for obtaining higher grain yield, as well as nitrogen is the most important plant nutrient needed to obtain high wheat yields in Egypt. A beneficial effect of nitrogen application on wheat gave the highest values of number of spikes $\mathrm{m}^{-2}$, plant height, spike length number of spikelets spike $^{-1}$, 1000-grain weight and grain and straw yields of wheat with increasing $\mathrm{N}$ level (Sawires, 2000 and Sobh et al., 2000). Increasing chemical nitrogen fertilizer level from 75 to 150 or $225 \mathrm{~kg} \mathrm{~N} \mathrm{ha}{ }^{-1}$ caused significantly increased growth, yield and yield attributes (Abd El-Maksoud, 2002 and Saleh, 2002). Increasing nitrogen fertilizer rates from 72,144 to $216 \mathrm{~kg} \mathrm{~N}^{-1}$ significantly increased number of spikes $\mathrm{m}^{-2}$ and straw and grain yields ha $^{-1}$ (Salem, 2005; Saad, 2007; ElGizawy, 2005 and Abedi et al., 2010). However, the highest yield was produced due to application of $180 \mathrm{~kg} \mathrm{~N} \mathrm{ha}^{-1}$ (Abd El-Razek and ElSheshtawy, 2013) as well as increasing $\mathrm{N}$ up to $75 \mathrm{~kg}$ fed. ${ }^{-1}$ increased yield and its attributes of wheat in both growing seasons (Noureldin, Nemat, et al., 2013). On the other hand, the application of different $\mathrm{N}$ rates had no significant effect on the number of spikes $\mathrm{m}^{-2}$, number of 
spikelets spike ${ }^{-1}$ and 1000-kernel mass in both seasons (Maali and Agenbag, 2004). Therefore, the present work was undertaken to determine the quantitative requirements different rates of compost and $\mathrm{N}$ fertilization limits in relation to grain yield response under New Valley condition.

\section{Materials and Methods:}

Two field experiments were conducted out at El-Dakhla Oasis, New Valley Governorate, Egypt, dur- ing the two winter growing seasons of 2011/2012 and 2012/2013 to investigate the effect of date palm compost and nitrogen fertilizer rates on the yield and yield components of bread wheat grown in the New Valley. The soil texture was clay loam. Soil samples were collected to depth of $30 \mathrm{~cm}$ from the experimental site. Detailed results as the mechanical and chemical analysis of the soil in both seasons are presented in Table (1).

Table 1: Some physical and chemical properties of a representative soil sample from the experimental site in 2011/2012 and 2012/2013.

\begin{tabular}{|c|c|c|c|c|c|c|c|c|c|c|c|}
\hline \multirow[b]{2}{*}{ Season } & \multicolumn{4}{|c|}{ Physical } & \multicolumn{7}{|c|}{ Chemical } \\
\hline & 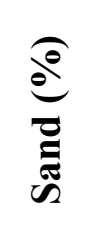 & $\underbrace{e^{e}}_{i=\frac{e}{e}}$ & $\underbrace{e^{e}}_{\frac{\vec{a}}{0}}$ & 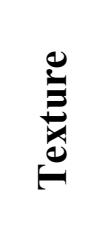 & $e_{\tilde{U}}^{\infty} e^{\varrho}$ & $\underbrace{e^{e}}_{\frac{e}{0}}$ & 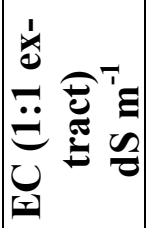 & $\ddot{\ddot{\pi}}$ & $\frac{Z}{0} e^{\frac{\pi}{0}}$ & 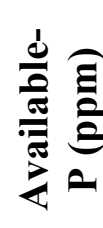 & 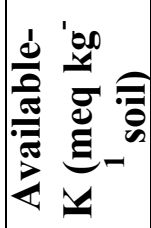 \\
\hline $2011 / 2012$ & 29 & 40 & 31 & $\begin{array}{l}\text { Clay } \\
\text { loam }\end{array}$ & 1.12 & 1.90 & 1.21 & 7.9 & 0.35 & 16.2 & 2.0 \\
\hline $2012 / 2013$ & 28.5 & 41 & 30.5 & $\begin{array}{l}\text { Clay } \\
\text { loam }\end{array}$ & 1.10 & 1.91 & 1.19 & 7.7 & 0.32 & 16.4 & 2.1 \\
\hline
\end{tabular}

Some properties of date palm compost are presented in Table 2 .Date palm compost was mixed with the soil before two weeks from sowing.

Table 2: Some properties of date palm compost (organic fertilizer).

\begin{tabular}{|l|c|}
\hline \multicolumn{1}{|c|}{ Characters } & Value \\
\hline $\mathrm{pH}(1: 10$ suspension) & 8.38 \\
$\mathrm{ECe}(1: 10) \mathrm{dS} / \mathrm{m}$ & 3.45 \\
Total-N (\%) & 0.90 \\
Total-P (\%) & 0.79 \\
Total-K (\%) & 0.94 \\
Organic matter (\%) & 26.97 \\
Organic carbon (\%) & 15.64 \\
C/N ratio & 17.38 \\
Ash (\%) & 73.00 \\
\hline
\end{tabular}

The preceding crop was maize in both seasons of the study. A randomized complete block design using split-plot arrangement of treatments with three replications was employed.
The main plots were allocated for three rates of date palm compost i.e. 0,5 and $10 \mathrm{~m}^{3}$ fed. ${ }^{-1}$. The sub-plot assigned for three nitrogen fertilization rates i.e. 50,70 and $90 \mathrm{~kg} \mathrm{~N}$ 
fed. ${ }^{-1}$ as ammonium nitrate $(33.5 \%$ $\mathrm{N}$ ), which was applied into three equal doses, before the first, second and third irrigations. The experimental unit area was $10.5 \mathrm{~m}^{2}$ (3 m width x $3.5 \mathrm{~m}$ length). An activation dose at a level of $15 \mathrm{~kg} \mathrm{~N}$ fed. ${ }^{-1}$ was added to each sub-plot including those of the control at sowing. The grains of Sids12 cultivar were sown by handbroadcasting at a seeding rate of 60 $\mathrm{kg}$ fed. $^{-1}$ on $26^{\text {th }}$ and $24^{\text {th }}$ Nov. in the first and second seasons, respectively. All agricultural practices were done as recommended for wheat production, at El-Dakhla Oasis.

\section{Data recorded:}

At harvest (at the end of April) a sample of ten plants from square meter was randomly chosen from each sub-plot in three replicates to measure number of spikes $\mathrm{m}^{-2}$, spike length, spikelets number spike ${ }^{-1}$ and weight of 1000-grains as well as plant height. Grain and straw yields per feddan were calculated from the whole plants of each plot for the three replicates in kilograms, and converted into ardab and ton per feddan, respectively.

\section{Statistical analysis:}

The obtained data from each season were exposed to the prober statistical analysis of variance according to Gomez and Gomez (1984), using the computer MSTAT statistical analysis described by CoStat (2004). The revised least significant difference test (Rev. L.S.D.) at 5\% level of probability was computed to detect the differences among means.

\section{Results and Discussion:}

\section{Effect of date palm compost:}

Data in Table 3 showed that the plant height, spikelets number spike ${ }^{-1}$ and straw yield in the $1^{\text {st }}$ season and grain yield in the $2^{\text {nd }}$ season as well as spikes number $\mathrm{m}^{-2}$ in both seasons had a significantly affected by the date palm compost. The other traits had non-significant affected by this treatment either in the $1^{\text {st }}$ or the $2^{\text {nd }}$ season. It is clear that the compost application gave a significant increase in plant height and straw yield fed. ${ }^{-1}$ in the $1^{\text {st }}$ season and spikes number $\mathrm{m}^{-2}$ and grain yield fed. ${ }^{-1}$ in the $2^{\text {nd }}$ season as compared with the control treatment. The tallest plant $(98.03$ and $97.83 \mathrm{~cm})$ and the maximum straw yield (3.46 and 3.92 ton fed. ${ }^{-1}$ ) were achieved as $5 \mathrm{~m}^{3}$ fed. $^{-1}$ compost in the $1^{\text {st }}$ and the $2^{\text {nd }}$ seasons, respectively. This is logic, the high straw yield depend on the length of plant. Likewise, the highest spikes number $\mathrm{m}^{-2}(500.7)$ in the $2^{\text {nd }}$ season and the maximum grain yield (18.80 and 19.10 ard. fed. ${ }^{-1}$ ) in both seasons were recorded by applying $5 \mathrm{~m}^{3}$ fed. ${ }^{-1}$ compost. Also, this is logic, because of the spikes number $\mathrm{m}^{-2}$ one of the important factor for the crop triangle, therefore, the increase of spikes number $\mathrm{m}^{-2}$ may be realized the increase as in grain yield fed. ${ }^{-1}$. It is indicated that the highest spikelets number spike $^{-1}$ (19.43 and 17.00) were observed at $10 \mathrm{~m}^{3}$ fed. $^{-1}$ compost in both seasons. Although the insignificant effect of compost on the spike length in both seasons, the tallest spike (15.80 and 15.84) was detected by 10 $\mathrm{m}^{3}$ fed. $^{-1}$ compost in the $1^{\text {st }}$ and the $2^{\text {nd }}$ seasons, respectively and consequently the increase in spikelets number spike ${ }^{-1}$ was expected.

Ibrahim et al. (2008) mentioned that the tallest plant was recorded by the application of compost at $500 \mathrm{~kg}$ $\mathrm{ha}^{-1}$. They added that the spike length was non-significant and the maximum value was observed at $500 \mathrm{~kg}$ $\mathrm{ha}^{-1}$ compost, while the minimum one was observed at $400 \mathrm{~kg} \mathrm{ha}^{-1}$ compost. 
Compost not only slowly releases nutrient but also prevents the losses of chemical fertilizers through denitrification and volatilization as well as waste may be improve the efficiency of chemical fertilizer and thus reduce their use in order to improve crop productivity as well as sustain soil health and fertility (Abedi et al., 2010). Previous studies have shown that organic materials (compost, manures) enhance nutrient use efficiency by slow releasing of nutrients and reducing their losses (Muneshwar et al., 2001 and Nevens and Reheul, 2003). These findings are in conformity with those obtained by Bassal and Zahran (2002), Terrance et al. (2004), ElGhamry et al. (2009) and Agamy et al. (2012).

\section{Effect of nitrogen fertilizer rates:}

Data in Table 3 revealed that the spike length and 1000-grains weight in both seasons, as well as spikes number $/ \mathrm{m}^{2}$ in the $1^{\text {st }}$ season and straw and grain yields in the $2^{\text {nd }}$ season had a significantly or highly significantly affected by the application of nitrogen fertilizer rates. The other studied traits either in the $1^{\text {st }}$ or in the $2^{\text {nd }}$ season had non-significant affected by the same treatment. Generally, increasing nitrogen up to 70 and $90 \mathrm{~kg}$ fed. ${ }^{-1}$ increased yield and its components of wheat in both growing seasons (Table 3). It is clear that nitrogen application gave a significant increase for the spike length, 1000grains weight, spikes number $\mathrm{m}^{-2}$, straw yield and grain yield in the $1^{\text {st }}$ and / or in the $2^{\text {nd }}$ season as compared with the control treatment. Also, the plant height and spikelets number spike $^{-1}$ had insignificant increasing values with increasing nitrogen fertilizer rates as compared with the control treatment. The maximum straw yields ( 3.42 and 3.87 ton fed. ${ }^{-1}$ ) were accompanied with the tallest plants $(98.10$ and $98.07 \mathrm{~cm})$, where were realized with applying $70 \mathrm{~kg} \mathrm{~N}$ fed. ${ }^{-1}$ in the $1^{\text {st }}$ and the $2^{\text {nd }}$ seasons, respectively. The favorable effect of $\mathrm{N}$ fertilization on plant height and number of spikes $\mathrm{m}^{-2}$ may explain according to the role of nitrogen in stimulating cell division and elongation, consequently internodes elongation in addition and development. Meanwhile, the maximum grain yields (18.85 and 17.01 ard. fed. $^{-1}$ ) accompanied with the highest values of spikes number $\mathrm{m}^{-2}$ (489.0 and 497.3) were achieved by applying $70 \mathrm{~kg} \mathrm{~N}$ fed. ${ }^{-1}$ in the $1^{\text {st }}$ and the $2^{\text {nd }}$ seasons, respectively. Also, the tallest spikes (16.00 and $15.08 \mathrm{~cm})$ and the heaviest 1000grains (45.57 and $45.97 \mathrm{~g}$ ) were detected by adding $90 \mathrm{~kg} \mathrm{~N}$ fed. ${ }^{-1}$ in the $1^{\text {st }}$ and the $2^{\text {nd }}$ seasons, respectively. The increments in yield and its attributes of wheat with increasing $\mathrm{N}$ rates up to adequate $\mathrm{N}$ need might be attributed to the effective role of $\mathrm{N}$ as essential constituent of chlorophyll on dry matter accumulation. The improvement in wheat yield and its components under the acceptable increasing of $\mathrm{N}$ rates were obtained by Sobh et al. (2000) and Saudy et al. (2008). This indicates that presence of nitrogen led to less competition among plants for nitrogen and retarded leaf senescence, which increased period of photosynthesis and dry matter production and this turn help increasing grain yield. Noureldin, Nemat et al. (2013) concluded that increasing $\mathrm{N}$ up to $70 \mathrm{~kg}$ fed.$^{-1}$ increased yield and its attributes of wheat in both growing seasons. This was in accordance with results of Saleh (2002), Salem (2005), Maali and Agenbag (2004), Saad (2007), 
Abedi et al. (2010) and Abd El-Razek and El-Sheshtawy (2013).

\section{Effect of the interaction:}

Data in Table 4 showed that spike length in both seasons and spikelets number/ spike and spikes number $/ \mathrm{m}^{2}$ in the $1^{\text {st }}$ season and 1000 -grains weight, straw yield and grain yield in the $2^{\text {nd }}$ season, had a high significantly affected by the interaction between compost $\mathrm{x}$ nitrogen fertilizer rates. The other studied traits either in the $1^{\text {st }}$ and/or in the $2^{\text {nd }}$ season had non-significant affected by this interaction. It is clear that, the tallest spikes $(17.21$ and $16.05 \mathrm{~cm})$ followed by $(15.55$ and $15.25 \mathrm{~cm})$ were obtained by the $10 \mathrm{~m}^{3} \mathrm{fed}^{-1}$ compost with $90 \mathrm{~kg} \mathrm{~N}^{3} \mathrm{fed}^{-1}$ interactions followed by $5 \mathrm{~m}^{3}$ fed. ${ }^{-1}$ with 70 $\mathrm{kg} \mathrm{N}$ fed. ${ }^{-1}$ interactions in the $1^{\text {st }}$ and the $2^{\text {nd }}$ seasons, respectively. The shortest spikes (14.57 and $13.45 \mathrm{~cm}$ ) were observed by zero compost with $50 \mathrm{~kg} \mathrm{~N}$ fed. ${ }^{-1}$ interactions in the $1^{\text {st }}$ and the $2^{\text {nd }}$ seasons, respectively. Furthermore, the highest spikelets number spike ${ }^{-1}$ 20.10, 19.20 and 19.00 were recorded by $10 \mathrm{~m}^{3}$ fed. $^{-1}$ compost with 50,70 and $90 \mathrm{~kg} \mathrm{~N}$ fed. ${ }^{-1}$ interactions in the $1^{\text {st }}$ season, respectively. Also, the highest spikes number $\mathrm{m}^{-2}$ (526.3 and 516.0) followed by (497.0 and 486.0) were realized by 10 $\mathrm{m}^{3}$ fed. $^{-1}$ compost with both 90 and $70 \mathrm{~kg} \mathrm{~N}$ fed. ${ }^{-1}$ interactions, as well as the highest spikes number $\mathrm{m}^{-2}$ (493.0 and 530.0) followed by (485.0 and 500.0 ) were recorded by $5 \mathrm{~m}^{3}$ fed. $^{-1}$ compost with both 70 and $50 \mathrm{~kg} \mathrm{~N}$ fed. ${ }^{-1}$ interactions in the $1^{\text {st }}$ and the $2^{\text {nd }}$ seasons, respectively. 
Table 3: Wheat plant height, yield and yield attributes as affected by date palm compost and nitrogen fertilizer rates in 2011/2012 and 2012/2013 seasons.

\begin{tabular}{|c|c|c|c|c|c|c|c|c|c|c|c|c|c|c|c|}
\hline \multirow{2}{*}{\multicolumn{2}{|c|}{ Variables }} & \multicolumn{2}{|c|}{ Plant height (cm) } & \multicolumn{2}{|c|}{ Spike length (cm) } & \multicolumn{2}{|c|}{$\begin{array}{c}\text { Spikelets } \\
\text { number spike }^{-1} \\
\end{array}$} & \multicolumn{2}{|c|}{\begin{tabular}{|c} 
Spikes \\
number $\mathbf{~ m}^{-2}$ \\
\end{tabular}} & \multicolumn{2}{|c|}{$\begin{array}{l}\text { 1000-grains } \\
\text { weight (g) }\end{array}$} & \multicolumn{2}{|c|}{$\begin{array}{c}\text { Straw yield } \\
\text { (ton fed. }^{-1} \text { ) }\end{array}$} & \multicolumn{2}{|c|}{$\begin{array}{c}\text { Grain yield } \\
\text { (ardab fed. }^{-1} \text { ) }\end{array}$} \\
\hline & & $2011 / 2012$ & $2012 / 2013$ & $2011 / 2012$ & $2012 / 2013$ & $2011 / 2012$ & $2012 / 2013$ & $2011 / 2012$ & $2012 / 2013$ & $2011 / 2012$ & $2012 / 2013$ & $2011 / 2012$ & $2012 / 2013$ & $2011 / 2012$ & $2012 / 2013$ \\
\hline \multirow{3}{*}{$\begin{array}{l}\text { Compost } \\
\left(\mathrm{m}^{3} \text { fed. }^{-1}\right)\end{array}$} & 0 & $\begin{array}{c}92.38 \\
\mathrm{C}\end{array}$ & 95.87 & 15.07 & $\begin{array}{c}14.05 \\
\text { B }\end{array}$ & $\begin{array}{c}17.9 \\
\text { B }\end{array}$ & 15.93 & $433.8 \mathrm{~B}$ & $\begin{array}{c}453.3 \\
\text { B }\end{array}$ & 42.92 & 44.88 & $\begin{array}{c}3.02 \\
\text { B }\end{array}$ & $\begin{array}{c}3.48 \\
\mathrm{~B}\end{array}$ & 17.72 & $\begin{array}{c}17.98 \\
\text { B }\end{array}$ \\
\hline & 5 & $\begin{array}{c}98.03 \\
\mathrm{~A} \\
\end{array}$ & 97.83 & 15.43 & $\begin{array}{c}14.52 \\
\mathrm{AB} \\
\end{array}$ & $\begin{array}{c}18.17 \\
\mathrm{~B} \\
\end{array}$ & 15.67 & 472.3 & $\begin{array}{c}500.7 \\
\mathrm{~A} \\
\end{array}$ & 44.87 & 44.78 & $\begin{array}{c}3.46 \\
\mathrm{~A} \\
\end{array}$ & $\begin{array}{c}3.92 \\
\mathrm{~A} \\
\end{array}$ & 18.80 & $\begin{array}{c}19.10 \\
\mathrm{~A} \\
\end{array}$ \\
\hline & 10 & $\begin{array}{c}96.10 \\
\text { B }\end{array}$ & 96.73 & 15.80 & $\begin{array}{c}15.83 \\
\mathrm{~A}\end{array}$ & $\begin{array}{c}19.43 \\
\mathrm{~A}\end{array}$ & 17.00 & 484.1 & $\begin{array}{c}486.0 \\
\mathrm{~B}\end{array}$ & 45.48 & 44.25 & $\begin{array}{r}3.22 \\
\mathrm{AB} \\
\end{array}$ & $\begin{array}{r}3.69 \\
\mathrm{AB} \\
\end{array}$ & 17.83 & $\begin{array}{c}18,00 \\
\text { B }\end{array}$ \\
\hline \multicolumn{2}{|l|}{ F-test } & $* *$ & NS & NS & NS & $* *$ & NS & $*$ & $* *$ & NS & NS & $*$ & NS & NS & $*$ \\
\hline \multicolumn{2}{|l|}{ Rev. LSD 5\% } & 0.90 & - & - & 1.01 & 0.63 & - & 24.33 & 25.91 & - & - & 0.37 & 0.37 & 0.93 & 0.67 \\
\hline \multirow{3}{*}{$\begin{array}{l}\text { Nitrogen rate } \\
\left(\mathrm{kg} \text { fed. }{ }^{-1}\right)\end{array}$} & 50 & $\begin{array}{c}93.57 \\
\bar{B}\end{array}$ & $\frac{96.67}{\mathrm{~A}} \frac{67}{\mathrm{~B}}$ & $\frac{15.06}{\bar{B}}$ & $\frac{14.11}{\bar{C}}$ & 18.07 & $\frac{16.67}{\mathrm{~A}}$ & $\frac{438.8}{\bar{C}}$ & 462.0 & $\begin{array}{c}42.90 \\
\bar{B}\end{array}$ & $43.00 \mathrm{~B}$ & 2.98 & $\frac{3.43}{\bar{B}}$ & 17.69 & $\begin{array}{c}17.59 \\
\bar{B}\end{array}$ \\
\hline & 70 & $\frac{98.10}{\mathrm{~A}}$ & $\frac{98.07}{\mathrm{~A}}$ & $\frac{15.25}{\bar{B}}$ & 14.75 & 18.57 & $\begin{array}{c}15.87 \\
\bar{B}\end{array}$ & $\frac{489.0}{\mathrm{~A}}$ & 497.3 & $\frac{44.80}{\mathrm{~A}}$ & $\frac{44.43}{\mathrm{~A}} \frac{\overline{\mathrm{B}}}{\mathrm{B}}$ & 3.42 & $\frac{3.87}{\mathrm{~A}}$ & 18.58 & $\frac{19.01}{\mathrm{~A}}$ \\
\hline & 90 & $\frac{95.88}{\mathrm{~A}} \overline{\mathrm{B}}$ & $\begin{array}{c}95.70 \\
\bar{B} \\
\end{array}$ & $\frac{16.00}{\mathrm{~A}}$ & $\frac{15.08}{\mathrm{~A}}$ & 18.89 & $\frac{16.07}{\mathrm{~A}} \overline{\mathrm{B}}$ & $\begin{array}{c}460.2 \\
\bar{B}\end{array}$ & 480.7 & $\frac{45.57}{\mathrm{~A}}$ & $\frac{45.97}{\mathrm{~A}}$ & 3.25 & $\frac{3.80}{\mathrm{~A}}$ & 18.13 & $\frac{18.48}{\mathrm{~A}} \overline{\mathrm{B}}$ \\
\hline \multicolumn{2}{|l|}{ F-test } & NS & NS & $* *$ & $* *$ & NS & NS & $* *$ & NS & $*$ & $*$ & NS & $* *$ & NS & * \\
\hline \multicolumn{2}{|l|}{ Rev. LSD 5\% } & 4.28 & 2.42 & 0.43 & 0.25 & - & 0.74 & 20.62 & - & 1.84 & 1.70 & 0.36 & 0.21 & - & 1.38 \\
\hline
\end{tabular}

$\mathrm{NS}=$ Non-significant differences.

$*, * *$ indicated a significant and highly significant at $5 \%$ and $1 \%$ levels of probability.

Rev. LSD $=$ Revised least significant difference.

Means have the same letter within column did not differ significantly at 5\%

NS ( - ) indicated the all trait means did not differ significantly. 
Table 4: Wheat plant height, yield and yield attributes as affected by the interaction of date palm compost with nitrogen fertilizer rates in 2011/2012 and 2012/2013 seasons.

\begin{tabular}{|c|c|c|c|c|c|c|c|c|c|c|c|c|c|c|c|}
\hline \multicolumn{2}{|c|}{ Variables } & \multicolumn{2}{|c|}{$\begin{array}{l}\text { Plant height } \\
\text { (cm) }\end{array}$} & \multicolumn{2}{|c|}{$\begin{array}{l}\text { Spike length } \\
(\mathrm{cm})\end{array}$} & \multicolumn{2}{|c|}{$\begin{array}{c}\text { Spikelets number } \\
\text { spike }^{-1}\end{array}$} & \multicolumn{2}{|c|}{$\begin{array}{c}\text { Spikes } \\
\text { number } \mathbf{m}^{-2}\end{array}$} & \multicolumn{2}{|c|}{$\begin{array}{c}\text { 1000-grains } \\
\text { weight (g) }\end{array}$} & \multicolumn{2}{|c|}{$\begin{array}{l}\text { Straw yield } \\
\text { (ton fed. }^{-1} \text { ) }\end{array}$} & \multicolumn{2}{|c|}{$\begin{array}{l}\text { Grain yield } \\
\text { (ardab fed. }^{-1} \text { ) }\end{array}$} \\
\hline $\begin{array}{l}\text { Compost } \\
\mathrm{m}^{3} \text { fed. }^{-1} \\
\end{array}$ & $\begin{array}{c}\text { N-rate } \\
\text { kg fed. }^{-1}\end{array}$ & $\begin{array}{l}2011 / \\
2012 \\
\end{array}$ & 2012/2013 & $2011 / 2012$ & $2012 / 2013$ & $2011 / 2012$ & $2012 / 2013$ & $2011 / 2012$ & $2012 / 2013$ & $2011 / 2012$ & $2012 / 2013$ & $2011 / 2012$ & $2012 / 2013$ & $2011 / 2012$ & $2012 / 2013$ \\
\hline \multirow{3}{*}{0} & 50 & $90.60 \mathrm{c}$ & 94.70 & $14.57 \mathrm{c}$ & $13.45 \mathrm{~d}$ & $17.60 \mathrm{e}$ & 15.40 & $402.0 \mathrm{~d}$ & 430.0 & $44.30 \mathrm{~b}$ & $42.07 \mathrm{c}$ & $2.92 \mathrm{~b}$ & $3.70 \mathrm{c}$ & $16.92 \mathrm{~b}$ & $16.84 \mathrm{c}$ \\
\hline & 70 & $95.50 \mathrm{ab}$ & 97.10 & $15.35 \mathrm{bc}$ & $13.90 \mathrm{~cd}$ & $17.90 \mathrm{de}$ & 15.80 & $477.0 \mathrm{ab}$ & 476.0 & $44.17 \mathrm{a}$ & $44.00 \mathrm{bc}$ & $3.14 \mathrm{ab}$ & $3.75 \mathrm{ab}$ & $17.89 \mathrm{ab}$ & $18.88 \mathrm{ab}$ \\
\hline & 90 & $94.03 \mathrm{c}$ & 95.80 & $15.30 \mathrm{bc}$ & $14.25 \mathrm{c}$ & $18.27 \mathrm{e}$ & 15.80 & $415.0 \mathrm{~cd}$ & 454.0 & $44.30 \mathrm{a}$ & $44.07 \mathrm{bc}$ & $3.09 \mathrm{ab}$ & $3.60 \mathrm{abc}$ & $17.47 \mathrm{ab}$ & $18.21 \mathrm{abc}$ \\
\hline \multirow{3}{*}{5} & 50 & $96.00 \mathrm{ab}$ & 96.50 & $15.25 b c$ & $14.00 \mathrm{c}$ & $17.60 \mathrm{de}$ & 15.40 & $485.0 \mathrm{~b}$ & 500.0 & $44.50 \mathrm{a}$ & $43.47 \mathrm{bc}$ & $3.22 \mathrm{ab}$ & $3.63 \mathrm{ab}$ & $18.52 \mathrm{ab}$ & $18.85 \mathrm{ab}$ \\
\hline & 70 & $100.30 \mathrm{a}$ & 99.30 & $15.55 \mathrm{~b}$ & $15.25 \mathrm{~b}$ & $18.60 \mathrm{bcd}$ & 15.80 & $493.0 \mathrm{~b}$ & 530.0 & $45.73 \mathrm{a}$ & $43.60 \mathrm{~A}$ & $3.62 \mathrm{a}$ & $4.08 \mathrm{a}$ & $18.84 \mathrm{a}$ & $18.96 \mathrm{ab}$ \\
\hline & 90 & $97.80 \mathrm{ab}$ & 97.70 & $15.50 \mathrm{~b}$ & $14.95 \mathrm{~b}$ & $18.30 \mathrm{cde}$ & 16.60 & $439.3 \mathrm{c}$ & 427.0 & $46.20 \mathrm{a}$ & $47.27 \mathrm{a}$ & $3.54 \mathrm{a}$ & $4.06 \mathrm{ab}$ & $19.04 \mathrm{a}$ & $19.50 \mathrm{a}$ \\
\hline \multirow{3}{*}{10} & 50 & $94.10 \mathrm{bc}$ & 95.70 & $15.35 b c$ & $14.88 \mathrm{~b}$ & $19.00 \mathrm{~b}$ & 16.60 & $429.0 \mathrm{~cd}$ & 456.0 & $42.90 \mathrm{ab}$ & $43.47 \mathrm{bc}$ & $3.03 \mathrm{ab}$ & $3.55 \mathrm{bc}$ & $17.56 \mathrm{a}$ & $17.08 \mathrm{bc}$ \\
\hline & 70 & $98.50 \mathrm{ab}$ & 97.80 & $14.85 \mathrm{~b}$ & $15.10 \mathrm{~b}$ & $19.20 \mathrm{~b}$ & 16.80 & $497.0 \mathrm{ab}$ & 486.0 & $44.50 \mathrm{a}$ & $45.70 \mathrm{ab}$ & $3.50 \mathrm{ab}$ & $3.77 \mathrm{ab}$ & $19.01 \mathrm{a}$ & $19.20 \mathrm{a}$ \\
\hline & 90 & $95.80 \mathrm{ab}$ & 96.70 & $17.21 \mathrm{a}$ & $16.05 \mathrm{a}$ & $20.10 \mathrm{a}$ & 17.60 & $526.3 \mathrm{a}$ & 516.0 & $46.20 \mathrm{a}$ & $46.57 \mathrm{ab}$ & $3.12 \mathrm{ab}$ & $3.74 \mathrm{ab}$ & $17.80 \mathrm{ab}$ & $17.73 \mathrm{abc}$ \\
\hline \multicolumn{2}{|l|}{ F-test } & NS & NS & $* *$ & $* *$ & $* *$ & NS & $* *$ & NS & NS & $*$ & NS & * & NS & $* *$ \\
\hline \multicolumn{2}{|c|}{ Rev. LSD 5\% } & 4.81 & - & 0.79 & 0.46 & 0.71 & - & 36.44 & - & 3.43 & 3.20 & 0.62 & 0.52 & 1.71 & 1.92 \\
\hline
\end{tabular}

$\mathrm{NS}=$ Non-significant differences.

$*, * *$ indicated a significant and highly significant at $5 \%$ and $1 \%$ levels of probability.

Rev. LSD $=$ Revised least significant difference.

Means have the same letter within column did not differ significantly at 5\%

NS ( - ) indicated the all trait means did not differ significantly. 
The lowest spikes number $/ \mathrm{m}^{-2}$ (402.0 and 430.0) was obtained by zero compost with $50 \mathrm{~kg} \mathrm{~N}$ fed. $^{-1}$ interaction in the $1^{\text {st }}$ and the $2^{\text {nd }}$ seasons, respectively. It is observed that the maximum straw yields (3.62 and 4.08 ton fed..$^{-1}$ ) followed by (3.54 and 4.06 ton fed..$^{-1}$ ) were recorded by $5 \mathrm{~m}^{3}$ fed. ${ }^{-1}$ compost with $70 \mathrm{~kg} \mathrm{~N}$ fed. ${ }^{-1}$ interaction followed by $10 \mathrm{~m}^{3} \mathrm{fed}^{-1}$ compost with $90 \mathrm{~kg} \mathrm{~N}$ fed. ${ }^{-1}$ rate interactions in the $1^{\text {st }}$ and the $2^{\text {nd }}$ seasons, respectively. Meanwhile, the maximum grain yields (19.04 and $19.50 \mathrm{ard}$ fed. $^{-1}$ ) followed by (19.01 and 19.20 ard. fed. $\left.^{-1}\right)$ then (18.84 and 18.96 ard. fed. ${ }^{-1}$ ) were realized by 10 $\mathrm{m}^{3}$ compost with $90 \mathrm{~kg} \mathrm{~N}$ fed. ${ }^{-1}$ rate interaction followed by $5 \mathrm{~m}^{3} \mathrm{fed}^{-1}$ compost with $70 \mathrm{~kg} \mathrm{~N}$ fed. $^{-1}$ rate interactions in the $1^{\text {st }}$ and the $2^{\text {nd }}$ seasons, respectively. Abedi et al. (2010) found that the use of chemical fertilizer $\mathrm{N}$, in combination with compost, further enhanced the grains yield. Similar results were obtained by Parmer and Sharma (2002), Sarwar et al. (2007) and Sarwar et al. (2008). Also, $\mathrm{N}$-fertilizer in the presence of bio and organic fertilizers increased the decomposition and mineralization rate of organic fertilizers and the availability of nutrients for plant growth. The combination between the three kinds of fertilizers was significantly increased yield and its components than each of them singly. This was owing to the presence of nutrient elements and organic matter that prevented leaching of such mineral fertilizer (Agamy et al., 2012). Similar finding was reported on wheat plants by Salantur et al. (2006).

\section{References:}

Abd El-Maksoud, M.F. (2002). Response of some wheat cultivars to bio-fertilizer and nitrogen fer- tilizer levels. Zagazig J. Agric. Res. Egypt, 29 (3): 891-905.

Abd El-Razek, U.A. and A.M. ElSheshtawy (2013). Response of some wheat varieties to bio and mineral nitrogen fertilizers. Asian J. of Crop Sci., 5 (2): 200-208.

Abedi, T.; A. Alemzadeh and S.A. Kazemeini (2010). Effect of organic and inorganic fertilizers on grain yield and protein banding pattern of wheat. Aust. J. of Crop Sci., 4 (6): 384-389.

Agamy, R.A.; G.F. Mohamed and M.M. Rady (2012). Influence of the application of fertilizer type on growth, yield, anatomical structure and some chemical components of wheat (Triticum aestivum, L.) grown in newly reclaimed soil. Aust. J. of Basic and Appl. Sci., 6 (3): 561-570.

Bajpai, R.K.; S.K. Upadhyay, B.S. Joshi and R.S. Tripathi (2002). Productivity and economics of rice (Oryza sativa, L.), wheat (Triticum aestivum L.) cropping system under integrated nutrient supply systems. Indian J. Agron., 47: 20-25.

Bassal, S.A.A. and F.A. Zahran (2002). Effect of farmyard manure, bio and mineral nitrogen fertilizer and hill spaces on rice crop productivity. J. Agric. Sci. Mansoura Univ., 27: 19751988.

CoStat Statistical Software (2004). CoStat Manual Revision, 4 (2): 271.

El-Ghamry, A.M.; A.M. Abd ElHamid and A.A. Mosa (2009). Effect of farmyard manure and foliar application of micronutrients on yield characteristics of wheat grown on salt affected 
soil. American Eurasian J. Agric. \& Environ. Sci., 5 (4): 460465.

El-Gizawy, N.Kh.B. (2005). Yield and nitrogen use efficiency as influenced by rates and sources of nitrogen fertilizers of some wheat varieties. The $11^{\text {th }}$ Conference of Agronomy, Agron. Dept., Fac. Agric., Assiut Univ., Nov. 15-16: 51-64.

Gomez, K.A. and A.A. Gomez (1984). Statistical Procedures for the Agricultural Research. John Wiley and Sons, Inc., New York.

Ibrahim, M.; A. Ul-Hassan; M. Iqbal and Eh. Valeem (2008). Response of wheat and yield to various levels of compost and organic manure. Pak. J. Bot., 40 (5): 2135-2141.

Korsaeth, A.; T.M. Henriksen and L.R. Bakken (2002). Temporal changes in mineralization and immobilization of $\mathrm{N}$ during degradation of plant material: implications for the plant $\mathrm{N}$ supply and nitrogen losses. Soil Biol. Biochem., 34: 789-799.

Liu, E.; Ch. Yan; X. Mei; W. He; So H. Bing; L. Ding; Q. Liu; Sh. Liu and T. Fan (2010). Longterm effect of chemical fertilizer, straw and manure on soil chemical and biological properties in northwest China. Geoderma 158:173-180.

Maali, S.H. and A.G. Agenbag (2004). Effect of soil tillage, crop rotation and nitrogen application rates on grain yield of spring wheat (Triticum aestivum, L.) in the Swartland wheat producing area of the Republic of South Africa. (c. f. Abst. 57 (4): 1994).
Millner, P.D.; L.J. Sikora; D.D. Kaufman and M.E. Simpson (1998). Agricultural uses of biosolids and other recyclable municipal residues. P. 9-44. In: Agricultural Uses of Municipal, Animal and Industrial Byproducts. Conservation Research Reports 44, R.J. Wright, W.D. Kemper, P.D. Millner, J.F. Power and R.F. Korack (eds.). USDA Agricultural Research Survey, Washington, DC.

Mohammed, S.A. (2009). Composting of date palm wastes by using biological and natural additives. M.Sc. Thesis, Agron. Dept., Fac. Agric., El-Minia Univ., Egypt.

Muneshwar, S.; V.P. Singh; K.S. Reddy and M. Singh (2001). Effect of integrated use of fertilizer nitrogen and farmyard manure or green manure on transformation of $\mathrm{N}, \mathrm{K}$ and $\mathrm{S}$ and productivity of rice-wheat system on a Vertisol. J. Ind. Soc. Soil Sci., 49: 430-435.

Nevens, F. and D. Reheul (2003). The application of vegetable, fruit and garden waste (VFG) compost in addition to cattle slurry in a silage maize monoculture; nitrogen availability and use. Europ. J. Agron., 19: 189203.

Noureldin, Nemat, A.; H.A. Saudy; F. Ashmawy and H.M. Saed (2013). Grain yield response index of bread wheat cultivars as influenced by nitrogen levels. Ann. Agric. Sci., Ain Shams Univ., 58 (2): 147-152.

Parmer, D.K. and V. Sharma (2002). Studies on long-term application of fertilizers and manure on 
yield of maize-wheat rotation and soil properties under rainfed conditions in WesternHimalayas. J. Ind. Soc. Soil Sci., 50: 311-312.

Saad, M. (2007). Response of wheat to nitrogen fertilizer and water stress at different growth stages. M.Sc. Thesis, Agron. Dept. Fac. Agric., Assiut Univ., Egypt.

Salantur, A.; A. Ozturk and S. Akten (2006). Growth and yield response of spring wheat (Triticum aestivum $\mathrm{L}$.) to inoculation with rhizobacteria. Plant Soil Environ., 52: 111-118.

Saleh, M.E. (2002). Response of two wheat cultivars to seeding rates and nitrogen levels. Zagazig, J. Agric. Res., 29: 1367-1378.

Salem, M.A. (2005). Effect of nitrogen rates and irrigation regimes on yield and yield components of bread wheat (Triticum aestivum L.) genotypes under newly reclaimed land conditions. J. Agric. Sci., Mansoura Univ., Egypt, 30 (11): 6481-6890.

Sarwar, G.; N. Hussain; H. Schmeisky and S. Muhammad (2007). Use of compost on environment friendly technology for enhancing rice-wheat production in Pakistan. Pak. J. Bot. 39 (5): 1553-1558.
Sarwar, G.; N. Hussain; H. Schmeisky; S. Muhammad; M. Ibrahim and E. Safdar (2008). Improvement of soil physical and chemical properties with compost application in ricewheat cropping system. Pak. J. Bot. 40: 275-282.

Saudy, H.S.; M.S. El-Habbal; F. Ashmawy; E.M. Soliman and Kh. Abbas, Iman (2008). Using chlorophyll meter for predicting wheat nitrogen requirements. Ann. Agric. Sci., Moshtohor, 64 (4): 299-308.

Sawires, E.S. (2000). Yield and yield attributes of wheat in relation to nitrogen fertilization and withholding of irrigation to different stages of growth. Ann. Agric. Sci., Ain Shams Univ., 45 (2): 439-452.

Sobh, M.M.; M.S. Sharshar and A. Soad El-Sayed (2000). Response of wheat plants to nitrogen and potassium application in salt affected soil. J. Product, 5: 83-97.

Terrance, D.; M. Liebman; A. Cynthia; C.A. Cambardella and L. Richard (2004). Maize response to composting and time of application of solid swine manure. Agron. J., 96: 214-233. 


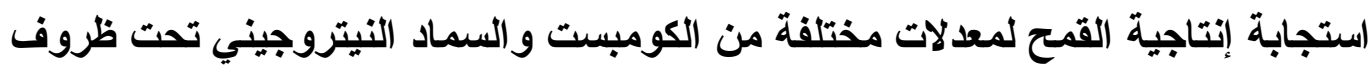 الوادي الجديد}

سيد هاشم عبدالله مسلم'، فتحي محمد فتحي عبد المتجلي'، جمال راجح النجار 'و رجب أحمد السيد داود'

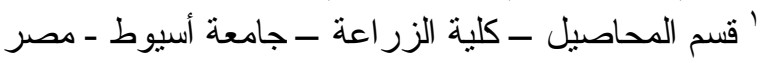

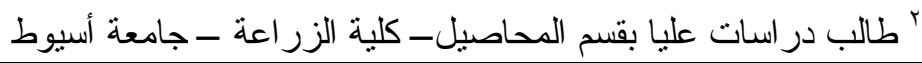

\section{الملخص:}

أقيمـت تجربتـان حقليتـان بواحـة الداخلـة محافظــة الـو ادي الجديـد بمسر خـلال موسـي الزر اعـة

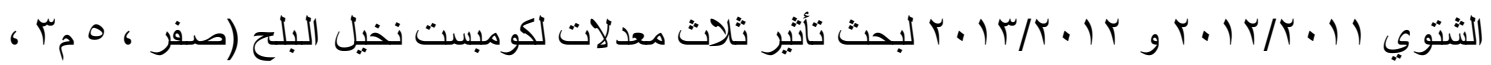

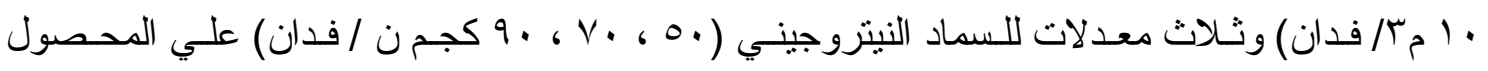
ومكوناته لقمح الخبز المنزر ع بالو ادي الجديد.

$$
\text { وكانت أهم النتائج هي: }
$$

ـ ـ عامة ز اد محصول القمح ومكوناته بإضـافة الكومبست ، و أعطت المعاملة ه مب/فدان كومبست أطول

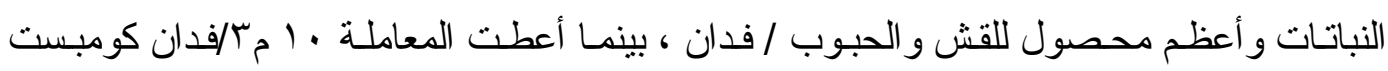

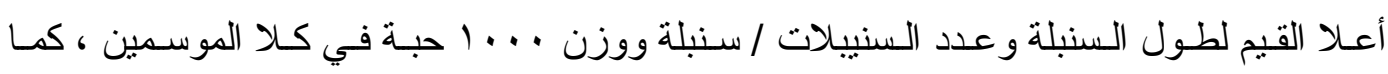

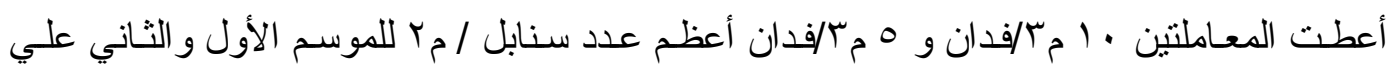
التزرتيب.

- ز اد محصول القمح ومكوناته بزيادة معدل السماد النيتروجينـي حتي • Vجم / فدان في كلا موسمي

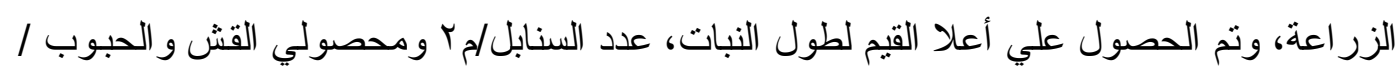
فدان باستخدام · V كجم ن / فدان ، بينما تم الحصول علي أطول سنبلة وأثقل . . . 1 حبـة باستخدام

$$
\text { . } 9 \text { كجم ن/فدان في كلا الموسمين. }
$$

- سجلت معاملة التفاعل ه مب/فدان كومبست مع معدل • كجم ن / فدان أطول النباتات و أعظم قيم لعدد

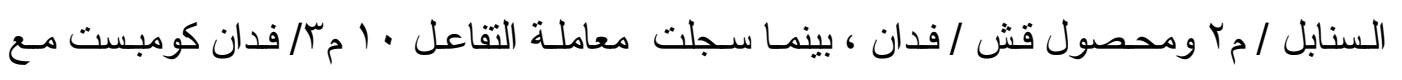
معدل • V كجم ن/فدان أعظم محصول حبوب / فدان في كلا الموسمين ـ ومن ناحيـة أخري سجلت

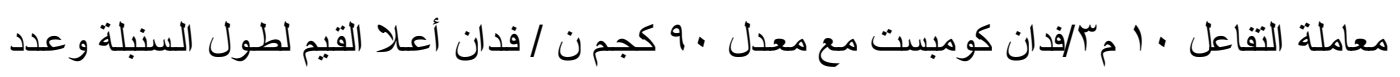

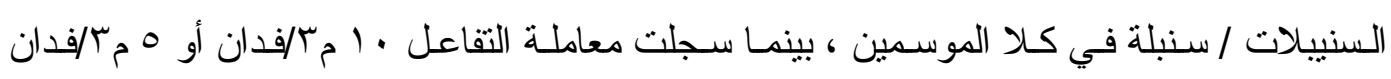
كومبست مع معدل و كجم ن / فدان أثقل . . . 1 حبة في كلا الموسمين. 